\begin{tabular}{l|l} 
Variants & $\begin{array}{l}\text { Variants } \\
\text { The Journal of the European Society for Textual } \\
\text { Scholarship }\end{array}$
\end{tabular}

15-16 | 2021

Textual Scholarship in the Twenty-First Century

\title{
Restricted Translation of Historical Dutch Text
}

\section{Hugo Maat}

\section{OpenEdition \\ Journals}

\section{Electronic version}

URL: https://journals.openedition.org/variants/1429

DOI: $10.4000 /$ variants. 1429

ISSN: 1879-6095

\section{Publisher}

European Society for Textual Scholarship

\section{Printed version}

Date of publication: 1 July 2021

Number of pages: 191-211

ISSN: 1573-3084

\section{Electronic reference}

Hugo Maat, "Restricted Translation of Historical Dutch Text", Variants [Online], 15-16 | 2021, Online since 01 July 2021, connection on 16 July 2021. URL: http://journals.openedition.org/variants/1429 ; DOI: https://doi.org/10.4000/variants. 1429 


\title{
Restricted Translation of Historical Dutch Text
}

Hugo Maat

\begin{abstract}
This article proposes an experimental approach to the diachronic translation of document sources written in historical variants of the Dutch language. It argues that, in order to make textual sources more accessible to read for modern audiences, it is possible to alter grammatical aspects of the text while preserving the lexical aspects of the historical language variant. Because of this restricted translation, this approach is less time consuming compared to a total translation. The article also describes a method for producing such texts, illustrated with examples taken from the sixteenth-century correspondence of William of Orange.
\end{abstract}

\section{Statement of Purpose}

This article presents and explains a novel approach to increase the accessibility of textual sources written in historical variants of the Dutch language. This approach was developed as part of a source edition project at the Huygens Institute for Dutch History (Huygens ING) in Amsterdam, in December 2019 ${ }^{1}$ The initial purpose was to develop a translation method for lay-oriented versions of historical source texts, specifically concerning the Dutch-language correspondence of William of Orange (1533-1584). Because of the large size of the text corpus, the project looked for an efficient method that would not require too much labour. A well-crafted translation in modern, legible Dutch, of a letter from the corpus in question, could take a translator as much as a full day to produce. The method discussed here, in first estimates, could process a thousand words in forty minutes, by instead rendering a "restricted translation", only targeting specific aspects of the historical language for the translation. The goal became to produce a text with increased legibility rather than a "total translation" (a translation whereby every aspect of the language in the source text is changed in the translated text), and thereby increase the accessibility of historical text. It requires manual translation, because automated translation would first require training data.

The following example is a transcript from a letter written in 1581 to the Prince of Orange and his council by the Landraad Beoosten Maas, one of the

1 The author worked as a research assistant for E. Dijkhof at the Huygens Institute in Amsterdam from October to December 2019. The project in question, to produce a new digital edition for the correspondence of William of Orange, was in early stages of development. The article was written for a research project for the department of Digital Infrastructure for the Royal Netherlands Academy of Arts and Sciences (KNAW). 
wartime provisional governing bodies in the Netherlands. The example includes the opening formula to illustrate that the letter contains only commas by way of punctuation. This remains true for the text from beginning to end, and is standard fare for this corpus of documentary sources.

Doerluchtige hoochgeboren furst genadige heer, ende Edele, Erentfeste, hoochgeleerde, wijse seer voorsienige heerene

Wij houden Uwe Furstliche Genade ende Edelen genaede Indachtich vandie deliberatien hier beuorens bij den Staten generall dick ende menichmall gehouden, op het toelaten offte geheelick verbieden vanden trafficque, commercie offte toeganck opdie Prouincien ende Steden, die bij onse vianden sijn geoccupeert, welcke deliberatien genoechsam Indien state gebleuen sijn dat geraden waere intselue geheelick mede op grote poenen te verbieden, doch Indien verstande, dat sulx van wegen dien van Franckrijck oick aenpaarlick soude hebben te geschieden Nu Ist sulx dat vermits eenige occurrentien die ons dienthaluen sijn voer gecomen ten aensiene vande Stede van Groeningenn shertogenbosch ende Breda, wesende binnen landtsche Steden ende denwelcken alle toeganck lichtelicker dan van andere souden mogen beleth worden, $[\ldots]$

(ARAB: Audiëntie 554 f. 179 r-180 v.)

The translation method alters the sentence structure and syntax while leaving most idiomatic elements of the text intact, rendering a version of the text that is not recognizable as present-day Dutch but considerably easier to interpret, in the sense that it requires less effort on the part of the reader.

\section{$[\ldots]$}

Wij houden Uwe Furstliche Genade ende Edelen genaede Indachtich vandie deliberatien, hier beuorens bij den Staten generall dick ende menichmall gehouden, op het toelaten offte geheelick verbieden vanden trafficque, commercie offte toeganck opdie Prouincien ende Steden, die bij onse vianden geoccupeert sijn.

Welcke deliberatien sijn genoechsam gebleuen Indien state, dat geraden waere intselue geheelick mede op grote poenen te verbieden, doch Indien verstande, dat sulx van wegen dien van Franckrijck oick aenpaarlick te geschieden soude hebben.

$\mathrm{Nu}$ Ist sulx: Eenige occurrentien sijn ons dienthaluen voer gecomen, ten aensiene vande Stede van Groeningenn shertogenbosch ende Breda, wesende binnen landtsche Steden, ende denwelcken alle toeganck lichtelicker dan van andere souden mogen worden beleth.

The initial project intended to produce a translation of the historical textual sources that was accessible to an audience of lay readers, for instance for educational purposes. The proposed method, which was developed as a spin-off, is primarily directed towards making historical texts more legible for scholars and researchers. This restricted translation specifically targets textual structure and grammar in historical language text. These are considered the main challenges because they prevent readers from employing reading strategies based on text 
structure, and because reference material is more suitable for resolving lexical elements of the text. A modern reader can relatively easily find the meaning of individual words through online resources such as the Historische Woordenboeken (Historical Dictionaries) on the website of the Institute for the Dutch Language (INT). The Historische Woordenboeken is an online dictionary that incorporates several historical Dutch dictionaries, accounts for variant spelling, and groups search results by time period ${ }^{2}$

The key idea behind this approach to translating historical text is that there is an imaginary "tipping point" for the degree to which a translator alters a text in the process of translation. In a total translation, the text is altered on every level. With the translation of historical text to a rendition in modern language, that covers spelling, vocabulary, grammar, structure and punctuation, and idiomatic elements. The tipping point as part of that design denoted the point at which the translation method would cover so many aspects that there would be no significant difference with a total translation in regard to effort required. A not-insignificant motivation for the development of and research into such a translation method is an interest in cost-effective solutions. Translations, after all, require human labour, and a translation of historical text requires specific additional skills. The question addressed in this article is whether it is possible to improve accessibility of a historical text through restricted translation, and what such a translation method would entail.

This article prefaces the explanation of the translation method with a discussion of intralingual translation, both manual and automatic, and the linguistic concepts used in the design. Intralingual translation is a relatively overlooked topic within translation studies, and textual scholarship tends not to incorporate these disciplines. Editions of historical texts are published in modern language translations, but I have not been able to find theoretical discussions or linguistic analyses of these practices. There are discussions about whether or not such translations are possible or allowed, and discussions about dealing with stylistic textual characteristics, but there is a lack of comprehensive theory for how a diachronic translation is produced within textual scholarship. The theoretical basis is therefore the research into intralingual translation practice by Aage HillMadsen and automated machine translations, most of which were developed for modern languages. The proposed method in this article is divided into three parts, which are: parsing (dividing the original text into component clauses), clausal shift (changing clause ranks to create shorter sentences), and modal shift (resolving certain forms of grammar specific to historical Dutch). The steps in the method are illustrated with examples from historical Dutch source texts from the William of Orange project.

2 See https://ivdnt.org/onderzoek-a-onderwijs/lexicologie-a-lexico grafie/historische-woordenboeken. last accessed at August 7, 2020. 


\section{State of the art}

\subsection{The discussion of intralingual translation in Dutch literary studies}

The idea, though not the exact term, of intralingual translation has been a topic for debate amongst literary scholars in the Netherlands. The discussion pertains specifically to modernizing editions and translations of works considered to be part of Dutch literary heritage. From time to time, modernizing translations of Dutch literary works have drawn the ire of literary scholars 3 More often than not, the attitude of literary scholars is cautious or negative towards this practice. An interlingual translation or hertaling would after all alter the rhythm and tempo of a text, and because words are embedded in semantic fields it is rarely possible to find perfect equivalents for expressions or lexical words that have gone "out of date". A historical text remains a historical text in translation because of the customs and mentalities present in the text, which are themselves historical. At times, modern language conflicts with this. One such Dutch critic of translation practices, Marita Mathijsen, advocated that a hertaling should provide footnotes for words that lack true equivalents in modern language rather than translating them, and that the norms and structures of the original textual style should be maintained. She described this approach as "bending the knee to a lazy reading public" but also the only way to save historical literature in the Netherlands (Mathijsen 2003, 129). This attitude was met with criticism from other scholars who felt that this did not describe a hertaling, but a critical edition of a historical text (van Strien and Koppenol 2004, 247-57).

The approach to translation as presented in this method is not very suitable for literary texts. A literary translation has to account for stylistic elements; it treats both the source text and target text as works of art. By contrast, the method proposed here is concerned with the accessibility of the contents of the text, treating certain stylistic elements as obstructions. Take, for example, the rhythm of the text. A common element in many historical texts, when compared to a modern writing style, is the length of the sentences. In some cases, a $16^{\text {th }}$ century sentence can be the length of a paragraph, or even fill a page. When creating a literary translation, the translator should take into account whether this serves a stylistic function and might even consider authorial intent. This is not meant to say that a literary translator could never edit the structure of the text, because they might and this might be justified. The point here is not to define and prescribe a translation method for literature, but to note the complexity or even impossibility to create hard and fast rules for editing such texts. The proposed method, however, is meant as a limited set of hard and fast rules for textual editing. The source text will not be respected as an aesthetic object, and the method should be applied accordingly.

3 See Jansen 2007. Kuipers and Smeets 1996: van Oostendorp 2013 A non-Dutch discussion on a similar topic can be found in Taylor et al. 1996 


\subsection{Estimating readability}

There are no objective parameters to determine the accessibility or readability of a particular text. Research into textual comprehension in combination with language acquisition or education suggests there are several relevant factors at work, such as complexity and length of individual words, the use of anaphores (a word referring back to a word used earlier in a text to avoid repetition), and the length of sentences (Benjamin 2012, 64). Several of these factors are common-sense observations. There are other, more complex notions, such as intertextual cohesion, whereby the readability of any particular text is connected to the reader's access or familiarity with texts that are semantically similar. Studies suggest that the subjective, individual variation between readers and their assessment of the readability of a particular text. It is also important to incorporate the target audience as a factor into the assessment of readability. The efficacy of formulas used to estimate the readability for any particular text is contested, though quantitative analysis methods are promising (Benjamin $2012,78)$. The application of such methods is however difficult for the subject at hand, as they can only measure relative accessibility of a text. "Will a proposed method produce a text that is more readable than the source text?" is not the relevant question; "Is the translated text (sufficiently) readable?" is.

\subsection{Automated Text Simplification and Statistical Machine Translation}

In recent years there have been promising research projects on diachronic translation through quantitative methods. Several of these specifically used the Dutch language and its historical variants for developing Statistical Machine Translation (SMT) tools for "modernizing" translations (Tjong Kim Sang et al. 2017. 55; Domingo et al. 2017, 299). The reason for this is that there exists a significant corpus of the same texts in different historical variants of the Dutch language, made available through the CLIN27 project for translating historical text. The texts used for these studies were Bible translations from different time periods and Dutch literary classics from the $17^{\text {th }}$ century, which had counterparts in modern Dutch translations. The existence of such a corpus allowed for automated methods to be trained and refined, by having human and machine translators work together.

The projects that develop tools for automated diachronic translation produce clear advantages for translators. The results suggest that this method is quite successful at resolving the spelling variants of historical language variants for individual words and recognizing the words which were no longer part of the modern lexicon (Domingo et al. 2017, 303). The shared tests of the CLIN27 project have however not succeeded in approaching the quality of human translation or of gold standard translation methods in other fields, going by the error margins. Semantic shift over time is also still a challenge quantitative methods cannot yet sufficiently solve (Tjong Kim Sang et al. 2017. 60). Additionally, it 
should be noted that these studies were performed with favourable conditions, because of the corpus of historical documents and modern translations thereof. This is usually not possible with historical documents. Finally it is important to recognize the difference between correspondence, for which the proposed method was developed, and texts such as the Bible or literary works, most notably the difference in textual structure. It is unclear whether the techniques developed in the mentioned studies would be applicable, though the research into automated diachronic translation is ongoing.

There has been research into Automated Text Simplification (ATS) on a syntactic level for modern languages, which rely on shortening sentences and resolving complex grammatical structures. The syntactic approach to ATS (lexical and hybrid approaches for text simplification exist as well) has much in common with the proposed translation method for historical text. However, these ATS applications were developed for second language readers or readers with aphasia, and each application is language specific. (Modern) Dutch was in fact one of the early languages for which ATS applications were developed (Shardlow 2014. 63). As with the above examples of SMT, this approach would require annotated corpora of text to train a system, in order to automatically generate rules. In order to take advantage of the progress in automated translation, any diachronic translation will have to invest manual labour.

\subsection{Lay-oriented INTRA}

Despite being explicitly oriented towards the translation of historical texts, the proposed method does not use a specifically diachronic type of intralingual translation as a foundation. The diastratic or lay-oriented approach is used as the base concept instead. There is definitely a diachronic aspect to the translation method, but the intention and purpose of the target text are those of a diastratic translation. The primary goal of a diachronic translation is to create a text that is contemporary with its audience in the sense of language. The method proposed in this article is not meant to make texts read as if they were modern texts, but to make the source texts more accessible for readers.

A notable advantage of intralingual translation in specific and the linguistic approach to translation in general is the availability of terminology. In order to discuss and develop ways to translate texts it is vital to have a language system that describes this activity. The concepts and terminology used to create this method is that of Aage Hill-Madsen's 2014 dissertation Derivation and Transformation, which offers a descriptive linguistic study of translation practice in the language used in the field of commercial pharmaceutics. Hill-Madsen's study produced a typology of "shifts", the various microstrategies that translators can employ (Hill-Madsen 2014, 134; see also Baker and Saldanha|2009. 269).

To Hill-Madsen's knowledge (and mine) no similar research exists for diachronic intralingual translations. He attributes this to the lack of academic interest in the field of intralingual translation. An additional problem is the lack of data to use for research. It was possible for his study to build a corpus for the 
study of lay-oriented translation, because it was being done on a large scale with specific parameters for each individual text. In order to research translation strategies for diachronic translation one would need a corpus of source texts and target texts. Danish translation scholar Karen Zethsen, who incidentally was the supervisor of Hill-Madsen, made a cursory attempt in 2009 on a small scale using several generations of new Bible translations, similar to the CLIN27 project (Zethsen 2009. 797). This was a qualitative study, by far not as broad or thorough as Hill-Madsen's dissertation, meant to provide an example of the kind of research that could be done on intralingual translation.

\section{Definitions and concepts}

\subsection{Types of translation}

Within the field of translation studies, the type of translation that this method is designed to create is considered a diachronic intralingual translation. This means that it is a translation from a source text (ST) written in one variant of a language to a target text (TT) written in another variant of the same language, and the source language is a historical variant. The distinction between interlingual and intralingual translations is in certain cases open for debate, as the difference between two historical variants of the same language can sometimes be as great as the difference between two different contemporary languages.

In addition it is necessary to make a distinction between what is known as a total translation and a restricted translation 4 In the case of a total translation, the target text is rendered completely in the target language, affecting orthography, which words are used, and the grammar. A targeted or restricted translation only affects a specific level (or multiple specific levels) of language in the source text (Catford 1965. 22). The translation may focus on [X], but leave [Y] intact. For the purpose of this paper, the proposed method for improving the accessibility of the language of historical text will be treated as a restricted intralingual translation.

The concept of intralingual translation was described by Roman Jakobson in his 1959 essay "On Linguistic Aspects of Translation". In his essay, Jakobson distinguished three types of translation: he defined intralingual translation as translation to another variant of the same language; interlingual translation as translation to another distinct language; and intersemiotic translation as translation to a different medium (Jakobson 1959. 233-34). The focus here lies on the first category. Since Jakobson there have been a number of subcategories added to intralingual translation. The term dialectical translation is used to denote the process of rendering a text in a different dialect, for instance translating

4 The distinction between "total translation" and "restricted translation" is not to be confused with that between a "partial translation" and a "full translation". A partial translation denotes a translation of a fragment of the source text, while a full translation denotes the translation of the source text in its entirety. 
from British to American English. Diachronic translation is used for translation between historical variants, though this virtually always means changing the language of the text to the modern variation of that language, while the inverse is generally nonexistent. Interlingual translations of historical texts are usually diachronic. This has led to peculiar situations wherein a historical text has become more accessible in translation, even to native speakers of the language of the original text (Hill-Madsen 2014. 71). Diastratic translation (also sometimes called "paraphrase") describes the process by which a text is changed from expert-oriented to lay-oriented or vice versa.

Compared to interlingual translation, intralingual translation has been less examined by academia and held in less regard. This began already with Jakobson, who also described interlingual translation as "translation proper" in his seminal essay. Criticism has been leveled at the distinction of these two kinds of translation. For one, the matter of whether two languages are truly distinct or that one is a dialect of the other is arbitrary and can be a contentious subject. When it comes to diachronic translation, a case can be made that some historical variants of a language can be less accessible to a modern user of that language than contemporary versions of other languages. The difference in accessibility between Althochdeutsch and contemporary German is at least as great as the differences between modern Danish, Swedish and Norwegian (Schreiber 1993. 25-27). Furthermore, the distinction between intralingual and interlingual is far less relevant to automated machine translations, which treat a language variant no different than the languages that are considered to be languages in their own right, simply as sets of data (Shardlow 2014, 64).

\subsection{Intralingual translation outside of TS}

The process of rewriting a text to another variant of the same language, specifically for the accessibility of older texts for a contemporary audience, is known by several names depending on field of expertise or language. Within Dutch literary studies it is referred to as "hertaling", a portmanteau of "vertaling" (translation) and the prefix "her-" (comparable to the English "re-" in the sense of "anew"). This term does not translate easily. The same phenomenon has several terms in neighbouring language areas. In French, such as in the digital archives of the Sorbonne, the term actualiser is used, which has quite a broad meaning. Traduit en français moderne is also common. German terms include Aktualisierung and Umformulierung, of which the former is also used to denote a digital "update" and the latter means as much as "rewording". In the English language, this type of textual alteration is sometimes called rewording or "modernizing". In translation science textbooks some of these terms are used to describe intralingual translation or to provide alternative terms for it. There is a great deal of ambiguity, as each of these words have other meanings, which furthermore tend to be the meanings far more commonly used. When the concept "intralingual translation" is used, or its counterparts in the other languages mentioned, which are easily recognizable (intralinguale Übersetzung, intralinguale vertaling, 
or traduction intralinguale) it is virtually always within the field of translation science. Exceptions exist, as with the French medievalist and literary historian Michel Zink, who pioneered research into translations of historical variants of French language texts as well as into the medieval practice of similar types of translation (Galderisi and Vincensini 2015, 16).

Another reason to employ terminology derived from translation studies and linguistics is that it enables precise and detailed description of what actually happens in the course of the translation act. In other words, it provided the tools to develop and describe a method. It is important to note that scholars in the fields of translation science and intralingual translation generally work descriptively, rather than prescriptively. The studies used as reference material in the development of the proposed translation method were not written as instruction manuals for translators. Indeed, the reason why the proposed method was developed in the first place is because there is no instruction manual available for the type of textual alteration intended for the Correspondence of William of Orange-project. In some fields, the work of the translator is almost treated as if it were a type of black box, due to its inherently hermeneutic and subjective character. This does not mean that these types of translations are not made, because they are, in different language areas. There is as of yet, however, very little academic attention for this phenomenon. Furthermore, translations of older literary texts are at times carried out by commercial publishers who may not share considerations or practices with academic or scholarly translators. This practice varies in different parts of the world (Berk Albachten 571. 577).

\subsection{Structural, grammatical and lexical}

A restricted translation as proposed here presupposes that we can distinguish grammatical aspects from lexical ones in the ST. This distinction is made for pragmatic reasons and is arbitrary to a degree when it comes to translating a text. The lexical function or meaning of a word or morpheme can vary depending on the grammatical order of the sentence. These aspects of the text are intertwined in natural language. In the strictest sense, the process of translation cannot affect only the one element and not the other. As such, this method is designed to operate on the level of the grammar of the ST while leaving the lexical elements unchanged, while not assuming that such a distinction can be fully maintained in the translation act. When the adjustments on the grammatical level cause changes on the level of individual words present in the ST, this is acceptable provided that it does not reduce internal consistency of the resulting translation.

Grammar consists of syntax and morphology. The syntax determines which combinations of words form a sentence, while morphology determines how words are formed, and how they function. Within the translation method, the clausal shift is a translation strategy concerning syntax, while the modal shift concerns morphology. In addition, the clausal shift affects punctuation, which is not a grammatical aspect of the text but rather a structural one, operating on a level above the sentence. This is a necessary part of this method of translation 
because the historical language variant follows a different logic for the formation and visual representation of sentence structure.

\subsection{Shifts}

A "shift" in Translation Studies is a change that occurs in a text because of translation. The distinction of shift types in Derivation and Transformation serves to create the most granular descriptions of individual types of changes translators make. Hill-Madsen advises as such that the shifts themselves or that level of analysis should not be used for didactic or prescriptive purposes, only for analytical purposes. Hill-Madsen groups the numerous shifts distinguished in the course of his research by two different systems: "species" by frequency and "genera" by function. The genera are then ordered in a cline of "lay-orientedness". These are structural reorganization, ideational variation, clarification, concretization, de-compacting, neutralization and personalization (Hill-Madsen 2014, 262-69).

Conceived as such, these shifts each represent a specific microstrategy for translators, used to describe the various small-grained actions as part of a translation act. In this context, the two shifts of this method are used in a prescriptive rather than a descriptive sense, and cover several different textual adjustments. In a descriptive analysis of translation strategies, a shift indicates the smallest and most granular component of a translator's actions (Hill-Madsen 2014. 312). This applies to the prescriptive approach to translation as well, i.e. this method and instructional documents, but the two shifts of this method each have a potential ripple effect. Because of the interconnected nature of aspects of language, altering one aspect for a translation may necessitate further changes to the text. With the clausal shift, for instance, changing the class of a clause within a sentence structure may be linked to a change in word order or the inference of a subject. These changes can be described as shifts in their own right, but since they are the result of the initial clausal or modal shift they are not distinguished as parts of the method in their own right.

\section{The translation method}

The proposed translation method consists of three steps. The following section provides a summary of the method. The first step is parsing, in which the text is broken up into clauses, treating the verb as a point of orientation. The second step is clausal shift, in which new (shorter) sentences are formed by changing some of the subordinate clauses into main clauses, adding or altering punctuation to create a visible new structure. The third step is modal shift, in which specific conjugations, indicative of historical variants of Dutch, are normalized to their equivalents in modern common use.

The examples used in the following section are drawn from the correspondence of William of Orange. The corpus contains incoming and outgoing letters, and the Dutch language documents within it mostly concern matters of diplo- 
macy, law, and warfare (Hoekstra 2007, 117). The texts have been converted from handwritten sources by myself, through the transcription software of Transkribus ${ }^{5}$ Because of this, the source text has not been normalized in spelling, though the abbreviations in the original text have been resolved. While it is not required for the transcription to be normalized, it is helpful if abbreviations have been resolved as part of the transcription process, as the translation method does not incorporate this element 6

\subsection{First step: Parsing}

The proposed method restructures the ST on the level of clauses, which requires the translator to first identify and distinguish the clauses in the text. In the context of this translation method, this step is called "parsing". Both historical texts and source language variants contain inconsistent use of punctuation, and certain verb modes that differ from modern Dutch. Because of this, the parsing has to be done manually, at least until sufficient training data is available to develop automated solutions. The translator uses the verb or verb groups to determine the boundaries of each clause. No distinction is to be made between main clauses and subordinate clauses as part of this operation.

\subsection{Parsing example}

Returning to the excerpt from the introduction, this example shows the transition from the ST to a set of clauses. The source document (a manuscript letter) is only structured in lines of text, with no recognizable start or end of sentences or clauses.

Doerluchtige hoochgeboren furst genadige heer, ende Edele, Erentfeste, hoochgeleerde, wijse seer voorsienige heerene

Wij houden Uwe Furstliche Genade ende Edelen genaede Indachtich vandie deliberatien hier beuorens bij den Staten generall dick ende menichmall gehouden, op het toelaten offte geheelick verbieden vanden trafficque, commercie offte toeganck opdie Prouincien ende Steden, die bij onse vianden sijn geoccupeert, welcke deliberatien genoechsam Indien state gebleuen sijn dat geraden waere intselue geheelick mede op grote poenen te verbieden, doch Indien verstande, dat sulx van wegen dien van Franckrijck oick aenpaarlick soude hebben te geschieden $\mathrm{Nu}$ Ist sulx dat vermits eenige occurrentien die ons dienthaluen sijn voer gecomen ten aensiene vande Stede van Groeningenn shertogenbosch ende Breda, wesende binnen landtsche Steden ende denwelcken alle toeganck lichtelicker dan van andere souden mogen beleth worden, $[. .$.

(ARAB: Audiëntie 554 f. 179 r-180 v.)

5 See https://transkribus.eu (accessed on August 7, 2020).

6 The William of Orange project at the Huygens Institute uses the transcription software Transkribus, which offers transcribers options to annotate and resolve abbreviations. 
Note that the capitalization of words appears to be inconsistent. This is partially because of the transcription process, as there are multiple variations for the same grapheme in a manuscript, which cannot be consistently translated into the binary of upper and lower case. In the parsed version of this excerpt below, the verb groups have been underlined. Note that the line breaks made here do not always coincide with the ST commas.

Doerluchtige hoochgeboren furst genadige heer, ende Edele, Erentfeste, hoochgeleerde, wijse seer voorsienige heerene

/Wij houden Uwe Furstliche Genade ende Edelen genaede Indachtich vandie deliberatien

/hier beuorens bij den Staten generall dick ende menichmall gehouden, op het toelaten offte geheelick verbieden vanden trafficque, commercie offte toeganck opdie Prouincien ende Steden,

/die bij onse vianden sijn geoccupeert,

/welcke deliberatien genoechsam Indien state gebleuen sijn

/dat geraden waere

/intselue geheelick mede op grote poenen te verbinden,

/doch Indien verstande, dat sulx van wegen dien van Franckrijck oick aenpaarlick soude hebben te geschieden

$/ \mathrm{Nu}$ Ist sulx

/dat vermits eenige occurrentien die ons dienthaluen sijn voer gecomen ten aensiene vande Stede van Groeningenn shertogenbosch ende Breda, /wesende binnen landtsche Steden

/ende denwelcken alle toeganck lichtelicker dan van andere souden mogen beleth worden, $[\ldots]$

There are only two main clauses in this ST excerpt. The first starts right after the address, with the SVO structure of "Wij houden Uwe [etc.]", the second being "Nu Ist sulx", which would mean as much as "The situation now is:", which is followed by subclauses. The parsing follows the verbs in the text, as mentioned. There are additional verbs within the third line, set in cursive. These are gerunds or infinitives functioning as nouns. They are not part of the verb group, and therefore not taken into account for the parsing process. On the whole, this step requires only little editing judgement. There is a word group without a verb, "doch Indien verstande", which could stand on its own (assuming an unwritten but implied verb) or be included in the preceding or following part. Because many clauses are reconnected later on in the translation process, there is no need to be overly cautious with the few uncertain cases.

\subsection{Second step: Clausal shift}

This part of the translation is based on the shift in clause ranking. The objective of the first two steps in the translation method is for the TT to consist of shorter sentences than the ST. In order to achieve that, the ratio of subordinate clauses to main clauses needs to be changed in favour of main clauses. This means that a number of existing subordinate clauses become main clauses, and that 
these are combined with remaining subordinate clauses to form sentences. The sequence of clauses relative to one another in the text is to remain unchanged. "Clausal (ranking) shift" is the descriptor for this change, but in practice such a change requires a number of different actions from the translator caused by the shift in clause rank. Generally it will require a shift in the position of the verb within the clause, towards the subject and the start of the clause. Presentday Dutch favours the subject-verb-object sentence (SVO) structure, which the translator should strive to produce in the TT. The component clauses may rely on anaphora or lack a proper subject entirely, which can be resolved by giving the new sentences grammatical subjects in the form of proper nouns or names. This can be accomplished by repeating the appropriate subject from a previous sentence. Finally, the translator utilizes punctuation to indicate the new sentence structure.

This element of the method is the most susceptible to interpretation and requires a translator to make choices. In these choices, the translator follows the skopos-rule, to translate in a way that enables the text to function in the situation or for the people using it (Hill-Madsen 2014, 55). This means that the translator strives to rank the clauses in such a way that the information in the text becomes more accessible. The shortening of sentences affords the reader breaks in the reading process and compartmentalizes information (Shardlow 2014, 62) 7

\subsection{Clausal shift examples}

The example from the previous step is used again here to illustrate the restructuring of clausal and sentence structure.

Wij houden Uwe Furstliche Genade ende Edelen genaede Indachtich vandie deliberatien, hier beuorens bij den Staten generall dick ende menichmall gehouden, op het toelaten offte geheelick verbieden vanden trafficque, commercie offte toeganck opdie Prouincien ende Steden, die bij onse vianden geoccupeert sijn.

Welcke deliberatien sijn genoechsam gebleuen Indien state, dat geraden waere intselue geheelick mede op grote poenen te verbieden, doch Indien verstande, dat sulx van wegen dien van Franckrijck oick aenpaarlick te geschieden soude hebben.

$\mathrm{Nu}$ Ist sulx [dat]: [vermits] Eenige occurrentien sijn ons dienthaluen voer gecomen, ten aensiene vande Stede van Groeningenn shertogenbosch ende Breda, wesende binnen landtsche Steden, ende denwelcken alle toeganck lichtelicker dan van andere souden mogen worden beleth.

The (new) clausal rank in this excerpt is indicated by moving the relevant verb or verb groups in either of two directions. For the main clauses, to follow standard practice in modern Dutch, the finite verb should be close to the subject. In subclauses, on the other hand, the finite verb is placed at the end of the clause,

$7 \quad$ It is beyond the scope of this research to investigate the reason why the historical Dutch writing style employs much longer sentences in comparison to modern use. 
including in combined verb phrases. The historical language variant of these documents resembles the German language more than modern Dutch in this regard. Note also that there are transition words that are rendered obsolete by the new structure, in which case they can be removed by the translator. In some cases this may apply to entire short phrases (like "Soo ist dat...", which translates to "It is thus:") , which exist to mark transitions in the original text where in modern convention one might use paragraphs or line breaks instead.

The following excerpt, taken from a letter from the Prince's court from 1573, illustrates how the structural reorganization of the parsed text can require the inference of a new subject in the creation of new main clauses. The inferred subjects can be pronouns or repetitions of appropriate noun groups from earlier in the text. The goal for the translator is to reduce the amount of anaphora, similar to the syntactic approaches within ATS. The following excerpt has already been parsed following the first step of the translation method. It is worth noting that this specific ST does not contain punctuation of any kind, which is an infrequent but existing phenomenon in the corpus of the William of Orange correspondence. Punctuation has been added in the TT to improve the readability of the text.

\section{$[\ldots]$}

/Ghevende hem Remonstrant macht avthoriteyt ende speciael bevel by desen de selven by alle middelen ende wegen volgens de voorschreven versoucke

/by hem remonstrant aen ons gedaen

/daer toe te constringeren ende bedwingen

/Ordonneren ende bevelen eerhalve onse admiralen allen onsen Oversten Capiteynen hoops ende bevelsluyden

/Versoucken oock allen govverneurs Magistraten ende anderen dient aengaen mach /ende voor wye hy Remonstrant sich addresseren ende dese jegenwoirdighe thoonen sal $[\ldots]$

$$
\text { (KHA: A 11/XIV I/12, f. } 261 \text { r-v) }
$$

Wij ghevende hem Remonstrant macht avthoriteyt ende speciael bevel by desen de selven, by alle middelen ende wegen volgens de voorschreven versoucke by hem remonstrant aen ons gedaen, daer toe te constringeren ende bedwingen.

Wij Ordonneren ende bevelen eerhalve onse admiralen, allen onsen Oversten, Capiteynen, hoops, ende bevelsluyden. Wij versoucken oock allen govverneurs Magistraten ende anderen dient aengaen mach, ende voor wye hy Remonstrant sich sal addresseren ende dese jegenwoirdighe thoonen sal.

The clausal shift is the most invasive and complex procedure of the entire translation method, as it involves nearly every sentence of the source text. It relies on an effective verb-based parsing in the preceding step. The translator needs to employ judgement in these alterations as syntactic structures often have multiple possible translations. Some examples: 
/Voorts dient dese omme uwer F.G. te aduerteren, /dat aen ons clachtich geweest zijn eenige Landtluden vanden dorpen In schielandt onder uwer Excellentie protectie ende gouuernemen gheseten,

(KHA: A 11/XIV E/30)

Might be translated as:

1. [...] dat eenige Landtluden vanden dorpen In schielandt, gheseten onder uwer Excellentie protectie ende gouuernemen, aen ons clachtich geweest zijn.

2. [...] dat eenige Landtluden aen ons clachtich zijn geweest, vanden dorpen In schielandt gheseten onder uwer Excellentie protectie ende gouuernemen.

3. Dese dient omme uwer F.G. te aduerteren. Eenige Landtluden vanden dorpen In schielandt, onder uwer Excellentie protectie ende gouuernemen gheseten, zijn aen ons clachtich geweest.

While the following:

$[\ldots]$ /hier toe accerdeerde de toecoempste van deesen Jegenwoirdigen oirloege

/ter oirsaecke vanden welcken die Rivieren vander Maese Rhyn waele Lecke hebben haer corresponden opte stadt van dordrecht

/ende (Importeren aldaer het eeniche welvaert ende neeringe)

/geslooten zyn geweest

/ende die negotiatie vandien gehelycken gecesseert heeft Inder vorigen

(RAD: 3 Stadsarchieven, 621)

Might be translated as:

1. De toecoempste van deesen Jegenwoirdigen oirloege accerdeerde hier toe. Ter oirsaecke vanden welcken zyn die Rivieren vander Maese Rhyn waele Lecke, hebben haer corresponden opte stadt van dordrecht, (zij Importeren aldaer het eeniche welvaert ende neeringe) geslooten geweest. Die negotiatie vandien heeft gehelycken gecesseert Inder vorigen.

2. Hier toe accerdeerde de toecoempste van deesen Jegenwoirdigen oirloege, ter oirsaecke vanden welcken die Rivieren vander Maese Rhyn waele Lecke geslooten zyn geweest. Zij hebben haer corresponden opte stadt van dordrecht (ende Importeren aldaer het eeniche welvaert ende neeringe), ende die negotiatie vandien heeft Inder vorigen gehelycken gecesseert.

\subsection{Third step: Modal shift}

Whereas the previous step was mostly concerned with syntax, the third step is concerned with the morphology of the verb. There are certain verb modes that have either gone out of use in current-day Dutch or are used in a different way. These specific verb modes are easily recognizable and can be changed with only a relatively small impact on the contents of the text. In regards to translating $16^{\text {th }}$ century Dutch, this method is concerned with two forms of verb 
conjugation: the subjunctive or conjunctive mood (aanvoegende wijs) and the present participle (onvoltooid deelwoord) (van den Toorn et al. 1997, 308 and 321).

The subjunctive mode has gone out of use in modern Dutch, beyond a specific set of expressions, which themselves can evoke an antiquated feel. It is used, for instance, in liturgical language (Uw naam worde geheiligd - Hallowed be thy name, from the Lord's Prayer) or traditional phrases (Leve de koning - Long live the king). Most examples of subjunctive mood in the source texts can be replaced with indicative or imperative forms of the same verb without severely impacting the meaning of the text. No instance of subjunctive mood should be retained in the TT because this grammatical aspect is no longer used productively by Dutch readers.

The present participle is more complicated to deal with in a translation. Contrary to the subjunctive mood, it is a verb type that is still used productively in present-day Dutch. What has changed is that certain applications of the present participle have gone out of use and are difficult to understand for a modern reader (Duinhoven, 97-138). Inversely, this means that some instances of the present participle being used in the ST can be left unchanged in the translation. The distinction is generally left to the judgement of the translator, but some general guidelines can be formulated. First, all instances of present participles based on the verbs zijn (to be) and hebben (to have), i.e. zijnde and hebbende are to be considered characteristics of a historical language variant and should be changed. Second, modern Dutch uses present participles as adjectives or adverbs, not in absolute form. An absolute present participle often occurs in subclauses, and can be changed to another verb tense based on the clause rank.

\subsection{Modal shift examples}

ST: "[Wij] wesende nochtans oick well vanden aduise" (ARAB: Audiëntie 554. 554)

TT: Wij zijn nochtans oick well vanden aduise

ST: "wesende binnen landtsche Steden," ibid.

TT: Wat binnen landtsche Steden zijn

ST: "[zij] verzoekende daeromme aen ons" (KHA: A 11/XIV E/30)

TT: zij verzoeken daeromme aen ons

ST: “Wy ende onse lieve Neve de Grave vanden Marck hadden hem te dien eynde diversche opene missyve verleent ende gegeven, addresserende aende voorschreven capiteynen," (KHA: A 11/XIV E/30)

TT: $[\ldots]$ verleent ende gegeven, geadresseerd aende voorschreven capiteynen,

ST: "sich te transporteren aende bovengemeld capitain Jan claess spiegel 
ende anderen [die] de voorschreven Schepe ende goede genomen hebbende," (ibid.)

TT: $[\ldots]$ ende anderen die de voorschreven Schepe ende goede genomen hebben,

The translation of verbs from the conjunctive to the indicative mood tends to be rather straightforward. In modern Dutch, an irrealis mood like the conjunctive is usually expressed periphrastically, through the inclusion of some form of the verb zullen/zouden (van den Toorn et al. 1997. 304). Interestingly, this particular verb was already in use as an alternative to indicate irrealis (subjunctive or optative, there is no morphological distinction in Dutch grammar) without using the conjunctive mood in the $16^{\text {th }}$ century, as evident in the first example below:

ST: “Zijluden zouden (zoe verre het gebeurde dat den viandt hemluden tot eenighen tijden ouerliepe ende quame ijemandt te gecrijghen) hem te beter moghen excuseren," (KHA: A 11/XIV E/30)

TT: Zijluden zouden (zoe verre het zou gebeuren dat den viandt hemluden tot eenighen tijden zou ouerlopen ende ijemandt zou komen te gecrijghen) hem te beter moghen excuseren, ST: "dat de vyant overmits zyne macht

ende volck, twelck hy te velde hadde," (HUA: Staten van Utrecht Landsheerlijke Tijd 38)

TT: $[\ldots]$, twelck hy te velde zou hebben ST: "ten zy hemluiiden tot con-

servatie der selver stadt voersien werde van behoerlycke gratie" (RAD: 3 Stadsarchieven, 621)

TT: ten zy hemluiiden tot conservatie der selver stadt voersien zouden worden van behoerlycke gratie ST: "datmen die sonder vertreck stelle tot

volcoemen delivrantie" (ibid.)

TT: datmen die sonder vertreck tot volcoemen delivrantie zullen stellen

\section{Discussion}

A deliberately restrictive and prescriptive approach to translation may seem contrary to the nature of the translator's craft. The proposed method however has a different goal when compared to conventional translation. A successful translation in the conventional sense consumes the source text and destroys the source language. The restricted translation described here resembles the work of an editor or a publisher proof-reading a manuscript almost as much as the work of an interpreter. The target text and target language remain historical to an extent and do not obscure the origins or most of the semantics of the source, while becoming significantly more accessible. At the same time, one of the advantages of the digital age and the ease at which textual data can be stored is that the unmodified transcription can be retained for an audience. Both the 
method itself and its products may, because of this, provide translation with transparency.

The proposed method has its virtues for use in textual scholarship, though the extent of its applicability will vary depending on the nature of the textual project. The restricted translation requires a limited amount of labour from a translator and requires less expertise in its translator than a total translation would. After all, the method puts the greater focus on morphology over lexical aspects, which are unchanged from the ST. This makes the proposed method advantageous for use in textual scholarship projects with large corpora of historical textual sources. In the case of a historical ST a reader is required to parse and interpret the historical syntax in addition to engaging with other aspects of the historical text. This is the part that can be resolved through the described alterations.

The restricted translation is not without its downsides or challenges. First, there is no escape from the subjectivity of the translator. The proposed method prescribes several operations, but the translator retains a significant amount of responsibility when it comes to interpreting the text and choosing how to implement the prescribed changes. To be fair, this is true of all forms of translation, including machine translations, which reflect the subjectivity of the translators that developed it. At best, the proposed method can offer up an explanation for the nature of the changes and the reasoning behind the choices made in the reader's stead. The primary choice in this regard is the decision to mostly disregard lexical elements and spelling in favour of grammar in the course of translating. Such a question must be resolved through experimentation as restricted translation is at this time a new approach.

\section{Closing remarks}

In summation, the proposed method prescribes how to turn a text written in a historical variant of Dutch into a restricted translation that follows modern Dutch grammatical and syntactical structure, including such elements as punctuation, while not altering lexical aspects that belong to the historical language variant. This is accomplished by identifying the grammatical clauses in the text, which are not otherwise indicated by punctuation or capitalization (parsing), reorganizing them into a sentence structure that reflects modern textual conventions (clausal shift) and resolving certain grammatical elements that have fallen into disuse in modern Dutch (modal shift). The purpose of this proposed method is to improve the readability of historical source texts while not expending the time and effort required for a total translation. While a total translation would be more readable than a restricted translation, the option to produce total translations may not always be feasible or cost-effective.

This approach to textual editing is connected to the notion that the divide between historical texts and present-day readers goes deeper than historical variants in spelling, lexicon and grammar. Through the application of this method, the texts are given a visual structure that they did not originally have. 
Reading the original sources is much like listening to a spoken rendition, and to receive the information, one has to consume the text from beginning to end. Modern readers are accustomed to a visual style of text composition that uses elements like punctuation, sentences, paragraphs, line breaks, headers. All these textual elements benefit an audience that is visually oriented. This enables reading practices such as skimming, which a modern reader cannot apply to the historical text.

There are several opportunities remaining for future research. The first objective would be to explore the effectiveness of the research method and the extent to which the method can be carried out by other translators using the instructions. This will be accomplished by having volunteers make a translation of Dutch historical texts (from the aforementioned corpus) using an instruction document detailing the translation method. These participants are not instructed beforehand about the contents of the method. Multiple rounds of tests have been planned, and the feedback from participants on the clarity of the instructions and the effectiveness of the method are used to improve these tools in between tests. This way, the method and the accompanying instruction document undergo a series of iterative test phases ${ }^{8}$

Secondly, future research would serve to widen the scope of the translation method. This method was geared towards a historical variant of the Dutch language connected to a specific time period. Further research would endeavour to apply the same principles of diachronic translation to other time periods, or to historical variants of other languages. Efforts in this vein would require collaboration with researchers from applicable fields of expertise, especially concerning other modern languages. Finally, once a certain amount of text has been translated in this way, digital tools like NLP can be developed based on the training data to automate the translation process to some degree. This restricted translation is less hermeneutic than a total translation, and should be expected to be more receptive to machine-learning solutions.

\section{Bibliography}

ARAB, Algemeen Rijksarchief van België, n.d. "Audiëntie 554."

Baker, Mona and Gabriela Saldanha, 2009. Routledge Encyclopedia of Translation Studies. London: Routledge.

Benjamin, Rebekah G, 2012. "Reconstructing Readability: Recent Developments and Recommendations in the Analysis of Text Difficulty'." Educational Psychology Review 24(1), pages 63-88.

8 Due to the COVID-19 outbreak and security measures, it was not possible to perform sufficient tests with volunteers in a reliable fashion and controlled environment in time for the submission of this paper. 
Berk Albachten, Özlem, 571. "Intralingual Translation: Discussions within Translation Studies and the Case of Turkey." In A Companion to Translation Studies, edited by Sandra Berman and Catherine Porter, West Sussex: Wiley \& Sons.

Catford, John, 1965. A Linguistic Theory of Translation. Oxford: Oxford University Press.

Domingo, Miguel, Mara Chinea-Rios, and Francisco Casacuberta, 2017. "Historical documents modernization." The Prague Bulletin of Mathematical Linguistics 108(1), pages 295-306. Publisher: Sciendo.

Duinhoven, Antonius M, n.d. “De deelwoorden vroeger en nu." Voortgang: Jaarboek voor de Neerlandistiek 6, pages 97-138.

Galderisi, Claudio and Jean-Jacques Vincensini, eds., 2015. De l'ancien français au français moderne: Theories, pratiques et impasses de la traduction intralinguale. Turnhout: Brepols.

Hill-Madsen, Aage, 2014. Derivation and transformation: Strategies in lay-oriented intralingual translation. Aarhus: Department of Business Communication, Aarhus University.

Hoekstra, Rik, 2007. “Correspondentie totaal - patronen en trends in de briefwisseling van Willem van Oranje." In Uit diverse bronnen gelicht. Rijswijk: Quantes, edited by Eef Dijkhof and Michel van Gent, pages 117-31.

HUA, Het Utrechts Archief, n.d. "Staten van Utrecht Landsheerlijke Tijd."

Jakobson, Roman, 1959. “On Linguistic Aspects of Translation.” In On Translation, edited by Reuben A Brower, Cambridge: Harvard University Press, pages 232-39.

JANSEN, FRANK, 2007. "Hom of kuit Moeten de Nederlandse klassiekers hertaald worden?" Onze Taal 76, page 175. Library Catalog: www.dbnl.org Publisher: DBNL, Available from: https :

//www.dbnl.org/tekst/_taa014200701_01/_taa014200701_01_0108.php (Accessed: 2020-07-27).

KHA, Koninklijk Huisarchie Den HaAg, n.d.a. "A 11/XIV I/12."

KHA, Koninklijk Huisarchief Den HaAg, n.d.b. "A 11/XIV E/30."

Kuipers, MaArten and Karin Smeets, 1996. “'Die Pinkeltje is zo'n betweter af en toe...' Suzanne Braam over het hertalen van kinderboeken." Vooys 14(2), pages 38-42. Library Catalog: www.dbnl.org Publisher: DBNL, Available from: https :

//www.dbnl.org/tekst/_voo013199601_01/_voo013199601_01_0027.php (Accessed: 2020-07-27). 
MathijSen, marita, 2003. “Een knieval voor de luie lezer? Hertaling als enig redmiddel voor historische literatuur." Nederlandse Letterkunde 8, pages 113-29.

van Oostendorp, Marc, May 2013. “Handen af van Louis Couperus!” Library Catalog: www.neerlandistiek.nl, Available from: https: //www.neerlandistiek.nl/2013/05/handen-af-van-louis-couperus/ (Accessed: 2019-11-01).

RAD, RegionaAl Archief Dordrecht, n.d. "3 Stadsarchieven."

SchreIBER, M., 1993. Übersetzung und Bearbeitung: Zur Differenzierung und Abgrenzung des Übersetzungsbegriff. Tübingen: Gunter Narr Verlag.

Shardlow, Matthew, 2014. "A Survey of Automatic Text Simplification." International Journal of Advanced Computer Science and Applications, Special Issue on Natural Language Processing, pages 58-70.

van Strien, Ton and Johan Koppenol, 2004. "Enig redmiddel?" Tijdschrift voor Nederlandse Taal- en Letterkunde 120, pages 247-57.

Taylor, Jane H. M., E. McMorran, and G. Leclerq, 1996. Translation: Here and There Now and Then. Exeter: Elm Bank Publications.

Tjong Kim Sang, Erik, Marcel Bollman, Remko Boschker, Francisco Casacuberta, F. M. Dietz, Stefanie Dipper, Miguel Domingo, Rob van der Goot, J. M. van Koppen, and Nikola Ljubešić, 2017. “The CLIN27 shared task: Translating historical text to contemporary language for improving automatic linguistic annotation." Computational Linguistics in the Netherlands Journal 7, pages 53-64.

van den Toorn, M. C., J. Arian Van Leuvensteijn, and W. J. J. Pijnenburg, eds., 1997. Geschiedenis van de Nederlandse taal. Amsterdam: Amsterdam University Press.

Zethsen, Karen K., 2009. "Intralingual Translation: An Attempt at Description.” Meta 54(4), pages 795-812. 